\title{
The Reduced Recombination and the Enhanced Lifetime of Excited Electron in QDSSCs Based on Different ZnS and $\mathrm{SiO}_{2}$ Passivation
}

\author{
Ha Thanh Tung $\mathbb{D}^{1},{ }^{1}$ Nguyen Thu Thao, ${ }^{2}$ and Lam Quang Vinh $\mathbb{D}^{3}$ \\ ${ }^{1}$ Faculty of Physics, Dong Thap University, Dong Thap Province, Cao Lanh City, Vietnam \\ ${ }^{2}$ Ho Chi Minh City University of Science, Ho Chi Minh City, Vietnam \\ ${ }^{3}$ Vietnam National University, Ho Chi Minh City, Vietnam \\ Correspondence should be addressed to Ha Thanh Tung; httung@dthu.edu.vn
}

Received 10 January 2018; Revised 24 February 2018; Accepted 6 March 2018; Published 8 April 2018

Academic Editor: Guohua Wu

Copyright $\odot 2018 \mathrm{Ha}$ Thanh Tung et al. This is an open access article distributed under the Creative Commons Attribution License, which permits unrestricted use, distribution, and reproduction in any medium, provided the original work is properly cited.

\begin{abstract}
In this study, we focus on the enhanced absorption and reduced recombination of quantum dot solar cells based on photoanodes which were coated by different $\mathrm{ZnS}$ or $\mathrm{SiO}_{2}$ passivations using the successive ionic layer absorption and reaction methods. The quantum dot solar cells based on photoanode multilayers, which were coated with a $\mathrm{ZnS}$ or $\mathrm{SiO}_{2}$ passivation, increased dramatic absorption in the visible light region as compared with other photoanodes and reduced rapid recombination proccesses in photovoltaic. As a result, the performance efficiency of $\mathrm{TiO}_{2} / \mathrm{CdS} / \mathrm{CdSe}$ photoanode with $\mathrm{SiO}_{2}$ passivation increased by $150 \%$ and $375 \%$ compared with $\mathrm{TiO}_{2} / \mathrm{CdS} / \mathrm{CdSe}$ with $\mathrm{ZnS}$ passivation and $\mathrm{TiO}_{2} / \mathrm{CdSe}$ photoanode, respectively. For this reason, we note that the tandem multilayers can absorb more wavelengths in the visible light region to increase a large amount of excited electrons, which are transferred into the $\mathrm{TiO}_{2}$ conduction band, and decrease number of electrons returned to the polysulfide electrolyte from QDs when a $\mathrm{ZnS}$ or $\mathrm{SiO}_{2}$ passivation is consumed. Moreover, it is obvious that there was a far shift towards long waves in UV-Vis spectra and a sharp drop of intensity in photoluminescence spectra. In addition, the dynamic process in solar cells was carried out by electrochemical impedance spectra.
\end{abstract}

\section{Introduction}

In recent years, quantum dot-sensitized solar cells (QDSSCs) based on quantum dots (QDs) have been considerable interest as promising candidates to replace the dye-sensitized solar cells (DSSCs) because QDs have potential functions such as a high extinction coefficient, tunable bandgaps, a large intrinsic dipole moment, low processing cost compared to organic dyes [1,2], and generation of multiple excitons [3]. The QDs were used in QDSSCs as sensitizers which include $\mathrm{PbS}[4,5], \mathrm{PbSeS}$ [6], CdS [7], CdSe [8], CdTe [9], and ZnS [10]. The highest efficiency, which was achieved by Jara et al., was approximately $2.51 \%$ for $\mathrm{CuInS}_{2}$ [11] because the electrons in the $\mathrm{CB}$ of the QDs moved to the electrolyte and recombined or got blocked. Moreover, tandem multilayers can go up the power conversion efficiency in the QDSSCs.
Like for instance, Woo et al. [12] and Ravindran et al. [13] studied the QDSSCs based on the $\mathrm{TiO}_{2} / \mathrm{CdS} / \mathrm{CuInS}$ tandem multilayers and the power conversion efficiency was about $1.47 \%$. This photovoltaic performance was higher than those of the CdS and CuInS 2 QDs alone. However, the efficiency was still minor because of increased combination processes at the $\mathrm{QDs} / \mathrm{TiO}_{2}$ surface and plenty of electrons moving to the electrolyte.

Overall, this work illustrates the QDSSCs based on different tandem multilayered photoanodes to enhance absorption in the QDSSCs. In addition, $\mathrm{ZnS}$ and $\mathrm{SiO}_{2}$ coating layer was applied to the $\mathrm{TiO}_{2} / \mathrm{CdS} / \mathrm{CdSe}$ electrode to reduce recombination and electron movement to the electrolyte. Therefore, the efficiency of the QDSSCs can be an upward trend, particularly, compared with $\mathrm{TiO}_{2} / \mathrm{CdS}$ and $\mathrm{TiO}_{2} / \mathrm{CdSe}$ photoanodes. 


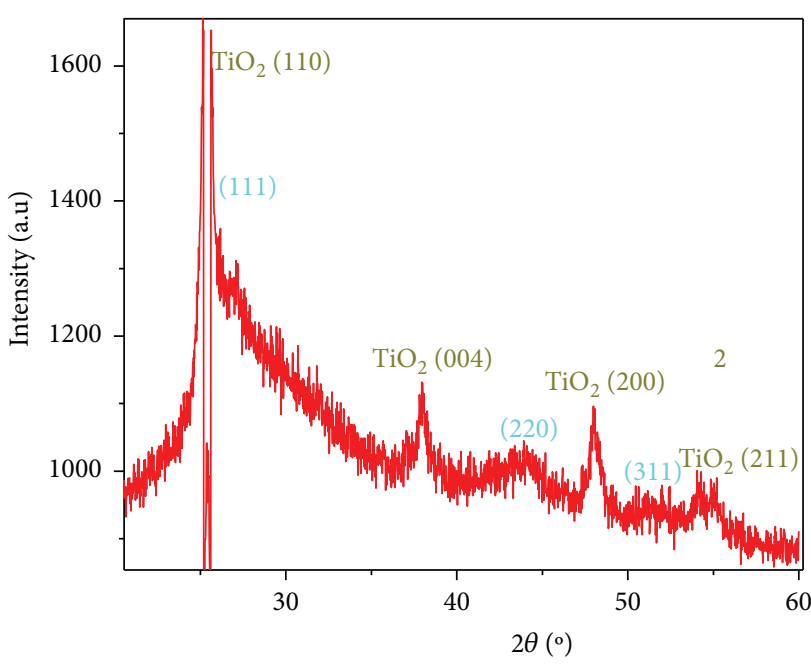

$\mathrm{TiO}_{2} / \mathrm{CdS} / \mathrm{CdSe}$

(a)

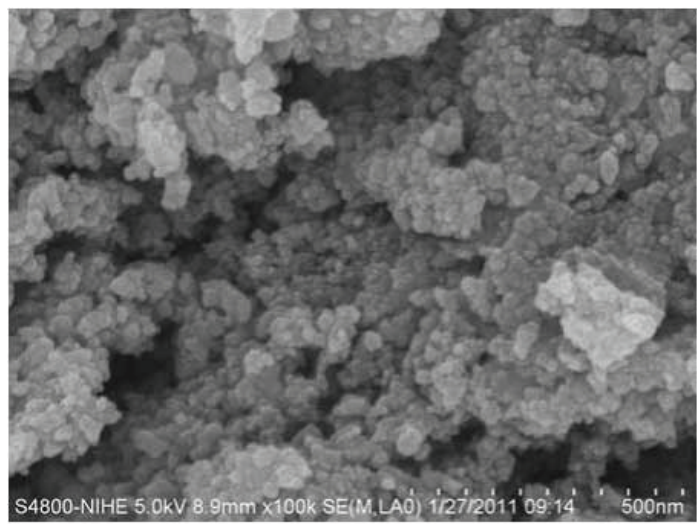

(c)

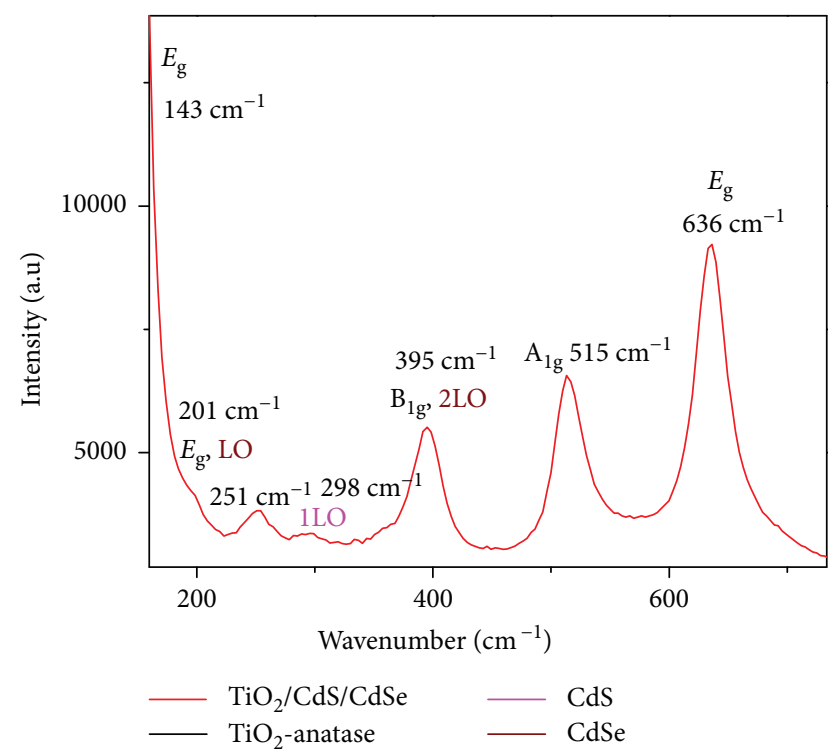

(b)

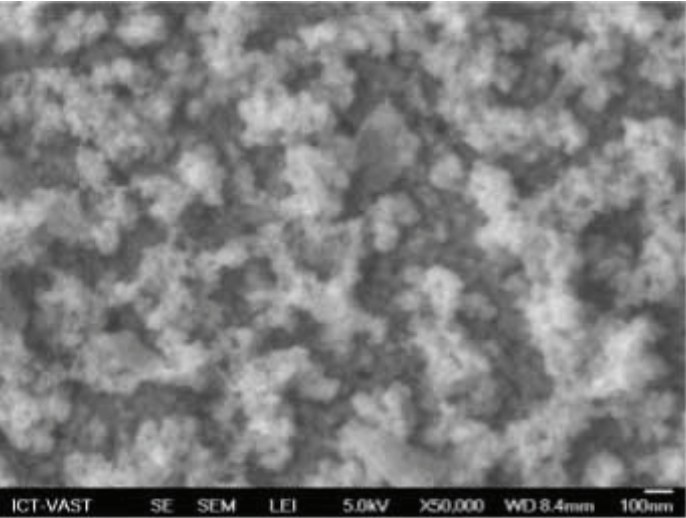

(d)

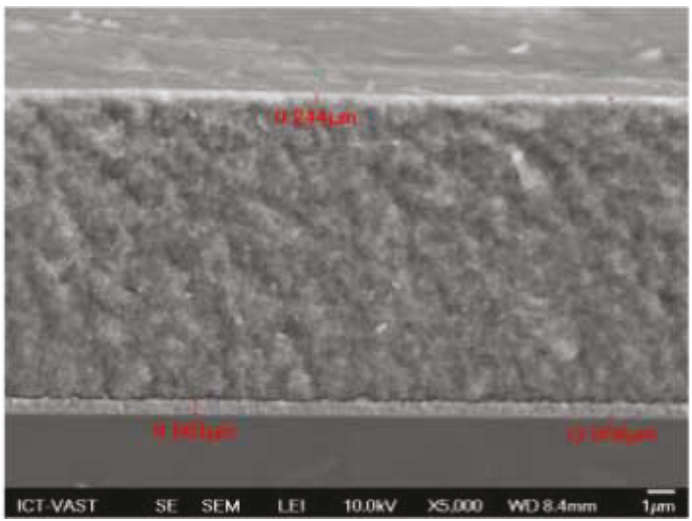

(e)

Figure 1: (a) X-ray diffraction patterns, (b) Raman spectra of $\mathrm{TiO}_{2} / \mathrm{CdS} / \mathrm{CdSe}$, (c) FESEM images of TiO ${ }_{2}$ film, (d) FESEM images of the $\mathrm{TiO}_{2} / \mathrm{CdS} / \mathrm{CdSe}$, and (e) cross-sectional FESEM of the $\mathrm{TiO}_{2} / \mathrm{CdS} / \mathrm{CdSe}$.

\section{Experiment}

2.1. Fabrication of $\mathrm{TiO}_{2}$ Films. There are two types of $\mathrm{TiO}_{2}$ pastes with different sizes: one type is small nanoparticles of $10-30 \mathrm{~nm}$ in which the light can be transmitted to the
QDs. Similarly, another is very large particles of $400 \mathrm{~nm}$ and it can become the light-scattering centers to orientate to the QDs. The FTO films were coated with $\mathrm{TiO}_{2}$ layers by silk-screen printing and annealed at $500^{\circ} \mathrm{C}$ for 30 minutes. Finally, the films were dipped in $40 \mathrm{mmol} \mathrm{TiCl}_{4}$ 


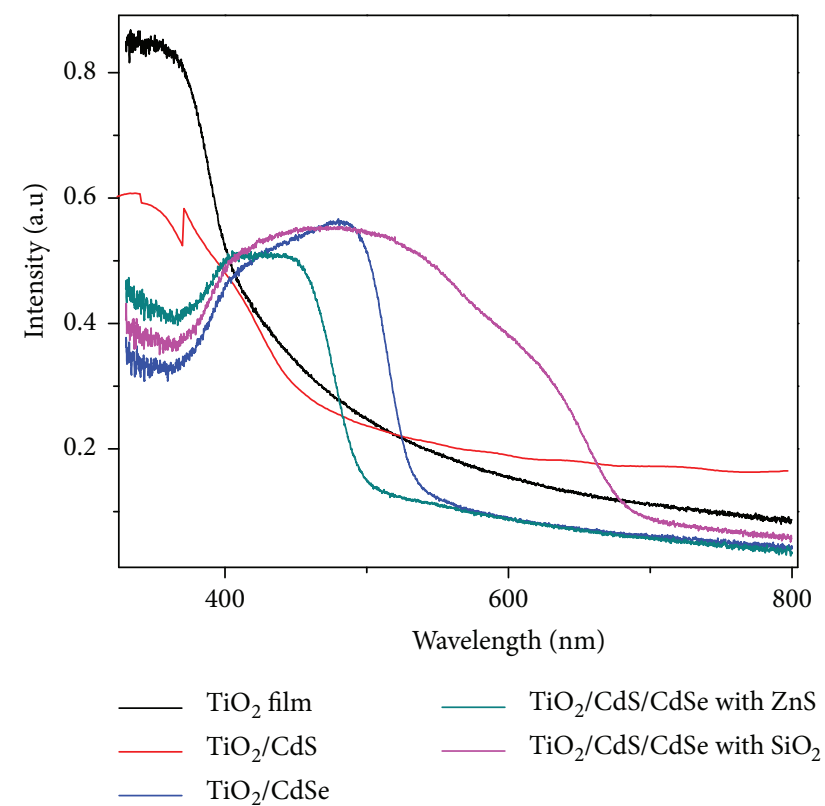

(a)

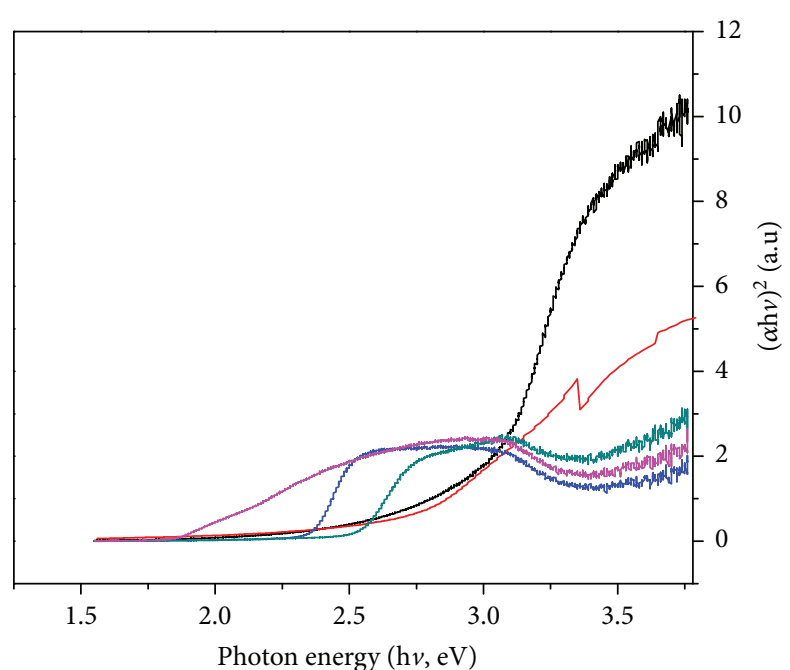

$\mathrm{TiO}_{2} / \mathrm{CdS} / \mathrm{CdSe}$ with $\mathrm{ZnS}$ $\mathrm{TiO}_{2} / \mathrm{CdS} / \mathrm{CdSe}$ with $\mathrm{SiO}_{2}$

(b)

FIGURE 2: (a) UV-Vis of different photoanodes and (b) plot $(\alpha \mathrm{h} v)^{2}$ versus the photon energy (hv) of different photoanodes.

solution for 30 minutes at $70^{\circ} \mathrm{C}$ and sintered at $500^{\circ} \mathrm{C}$ for 30 minutes.

\subsection{Fabrication of CdS and CdSe-Sensitized Photoanodes} with $\mathrm{ZnS}$ or $\mathrm{SiO}_{2}$. A $\mathrm{TiO}_{2} / \mathrm{CdS}$ was prepared by the SILAR. Firstly, the $\mathrm{TiO}_{2}$ film was dipped in $0.5 \mathrm{M} \mathrm{Cd}^{2+}$ solution for $1 \mathrm{~min}$ and $0.5 \mathrm{M} \mathrm{S}^{2-}$ solution for $1 \mathrm{~min}$ after being dried in the air to make one SILAR layer. Thickness of the electrode layer showed up in repeat of the three time layers. Secondly, the $\mathrm{TiO}_{2} / \mathrm{CdS}$ film was then dipped in $\mathrm{Cd}^{2+}$ solution for 5 min and $\mathrm{Se}^{2-}$ for $5 \mathrm{~min}$ after rinsing with Milli-Q ultrapure water to make one SILAR layer. Thickness of the $\mathrm{TiO}_{2} / \mathrm{CdS} /$ $\mathrm{CdSe}$ was increased in repeat of the three time layers. Finally, a $\mathrm{TiO}_{2} / \mathrm{CdS} / \mathrm{CdSe}$ film was dipped in $0.1 \mathrm{M} \mathrm{Zn}^{2+}$ solution for $5 \mathrm{~min}$ and $0.1 \mathrm{M} \mathrm{S}^{2-}$ solution for $5 \mathrm{~min}$ after rinsing with Milli-Q ultrapure water to make one SILAR layer. Thickness of the $\mathrm{TiO}_{2} / \mathrm{CdS} / \mathrm{CdSe}$ with $\mathrm{ZnS}$ layer had a growth in repeat the two time layers. Similarly, a $\mathrm{TiO}_{2} / \mathrm{CdS} / \mathrm{CdSe}$ was immersed in a beaker with an aqueous solution-mixed tetraethyl orthosilicate $(0.01 \mathrm{M})$ and $\mathrm{NaOH}(0.1 \mathrm{M})$ during $15 \mathrm{~min}$. After that, the films were rinsed with water and dried in air.

The QDSSCs were prepared with an active area of $0.192 \mathrm{~cm}^{2}$, a photoanode, and a cathode. The space between photoanode and counter electrode was filled with the polysulfide electrolyte, which consisted of $0.5 \mathrm{M} \mathrm{Na} \mathrm{N}_{2} \mathrm{~S}$, $0.2 \mathrm{M} \mathrm{S}$, and $0.2 \mathrm{M} \mathrm{KCl}$ in Milli-Q ultrapure water/methanol ( $7: 3$ by volume).

2.3. Characterization. The morphologies of samples were investigated using field emission scanning electron microscopy (FESEM). The crystal structure was analyzed using an X-ray diffractometer (Philips, PANalytical X'Pert, CuK $\alpha$ radiation). The absorption properties of the samples were investigated using a diffuse reflectance UV-Vis spectrometer
(JASCO V-670). The current-voltage $(J-V)$ characteristics of the QDSSC were measured under AM $1.5\left(100 \mathrm{~mW} / \mathrm{cm}^{2}\right)$ illumination, which was provided by a solar simulator (Oriel, USA), and recorded by a Keithley model 2400 digital source meter. Electrochemical impedance spectroscopy (EIS) measurements were obtained by an FRA-equipped PGSTAT-30 from Autolab. The measurements were performed in dark conditions at negative bias, and the frequency range was from $500 \mathrm{kHz}$ to $0.1 \mathrm{~Hz}$ with a modulation amplitude of $20 \mathrm{mV}$.

\section{Results and Discussions}

3.1. Structure and Morphology of Material. To obtain information about the QDs' size and crystalline photoanodes, the electrodes were annealed in vacuum at $200^{\circ} \mathrm{C}$. They were measured by using an X-ray diffractometer (XRD). Figure 1(a) illustrates the XRD of the $\mathrm{TiO}_{2} / \mathrm{CdS} / \mathrm{CdSe}$ photoanode. As can be seen from Figure 1(a), it is obvious that the XRD of photoanode clearly appears the strongest peak at $25.4^{\circ}$ position corresponding to the (101) plane which indicates an upstanding $\mathrm{TiO}_{2}$ anatase [14]. In addition, the XRD illustrates three peaks at $26.4^{\circ}, 44^{\circ}$, and $51.6^{\circ}$ corresponding to the (111), (220), and (311) planes of CdS and CdSe cubic phase [10]. Similarly, the crystallization of electrode was also determined by Raman spectra. It is noticeable that four modes are observed at $144 \mathrm{~cm}^{-1}, 397 \mathrm{~cm}^{-1}, 517 \mathrm{~cm}^{-1}$, and $638.5 \mathrm{~cm}^{-1}$ corresponding to phonon vibrations of $\mathrm{TiO}_{2}$ anatase [15]. Moreover, three peaks also appeared at $206.5 \mathrm{~cm}^{-1}$ and $395 \mathrm{~cm}^{-1}$, corresponding to phonons of longitudinal optical vibrations in CdSe and at $298 \mathrm{~cm}^{-1}$ corresponding to the longitudinal optical mode in CdS.

To observe shape of the photoanode, FESEM of the $\mathrm{TiO}_{2} /$ $\mathrm{CdS} / \mathrm{CdSe}$ electrode was carried out. It is obvious that the white $\mathrm{TiO}_{2}$ electrode became yellow and red because of the 
TABLE 1: The parameters obtained from UV-Vis.

\begin{tabular}{lcccc}
\hline Sample & $\begin{array}{c}\text { Wavelength } \\
\text { of absorption } \\
\text { edge }(\mathrm{nm})\end{array}$ & $\begin{array}{c}E_{\mathrm{g}} \\
(\mathrm{eV})\end{array}$ & $\begin{array}{c}E_{\mathrm{CB}} \\
(\mathrm{eV})\end{array}$ & $\begin{array}{c}E_{\mathrm{VB}} \\
(\mathrm{eV})\end{array}$ \\
\hline $\mathrm{TiO}_{2}$ & 443 & 2.80 & -4.3 & -7.5 \\
$\mathrm{TiO}_{2} / \mathrm{CdS}$ & 490 & 2.53 & -4.11 & -6.64 \\
$\mathrm{TiO}_{2} / \mathrm{CdSe}$ & 575 & 2.16 & -4.3 & -6.4 \\
$\mathrm{TiO}_{2} / \mathrm{CdS} / \mathrm{CdSe} / \mathrm{ZnS}$ & 594 & 2.09 & - & - \\
$\mathrm{TiO}_{2} / \mathrm{CdS} / \mathrm{CdSe} / \mathrm{SiO}$ & 679 & 1.83 & - & - \\
\hline
\end{tabular}

growth of CdS and CdSe (Figure 1(d)), compared to the FESEM of the pure $\mathrm{TiO}_{2}$ film. Looking at Figure 1(e), this is a cross-sectional FESEM of $\mathrm{TiO}_{2} / \mathrm{CdS} / \mathrm{CdSe}$, which is homogeneous and strongly adherent to the substrate and shows cutting shape of film with thickness of $12 \mu \mathrm{m}$. This also proves that CdS, CdSe, and QDs have successfully coated on the surfaces of $\mathrm{TiO}_{2}$.

3.2. The Optical Photoanodes. The optical CdS/CdSe-cosensitized $\mathrm{TiO}_{2}$ films can be monitored by studying the absorbance and energy bandgap of the materials. Figure 2(a) shows the $\mathrm{UV}$-Vis spectra with distrinct photoanodes. The absorption of the $\mathrm{TiO}_{2} / \mathrm{CdS} / \mathrm{CdSe}$ with $\mathrm{ZnS}$ or $\mathrm{SiO}_{2}$ passivation electrode is expanded through the visible region compared with other photoanodes. The absorbance of the $\mathrm{TiO}_{2} / \mathrm{CdS} / \mathrm{CdSe}$ with $\mathrm{SiO}_{2}$ passivation electrode progresses because the loaded $\mathrm{CdS}$ and CdSe concentrations on the $\mathrm{TiO}_{2}$ film can absorb more photons in the visible region from $400 \mathrm{~nm}$ to $700 \mathrm{~nm}$.

We can determine optical bandgap of materials based on the relation between the absorption coefficient $(\alpha)$ and the incident photon energy $(\mathrm{h} v)$ using Tauc [16].

$$
(a \mathrm{~h} v)=a_{\mathrm{o}}\left(\mathrm{h} v-E_{\mathrm{g}}\right) .
$$

Besides, to know materials inside, we can also calculate the position of conduction band and valence band for materials, which depend on energy bandgap of materials as follows:

$$
E_{\mathrm{CB}}^{\mathrm{o}}=E_{\mathrm{e}}-X+0.5 E_{\mathrm{g}},
$$

where

$$
X=\left[\left(x_{\mathrm{Cd}}^{x}\right) \times\left(x_{\mathrm{S}}^{y}\right)\right]^{1 /(x+y)}
$$

for CdS or

$$
X=\left[\left(x_{\mathrm{Cd}}^{x}\right) \times\left(x_{\mathrm{Se}}^{y}\right)\right]^{1 /(x+y)}
$$

for CdSe, and

$$
x_{\mathrm{M}}=0.5\left[E_{\mathrm{EA}}^{\mathrm{M}}+E_{\mathrm{ion}}^{\mathrm{M}}\right],
$$

with $\mathrm{M}=\mathrm{Cd}$, S, and Se. Where $E_{\mathrm{CB}}^{\mathrm{o}}$ is the conduction band potential, $E_{\mathrm{e}}$ is a given constant equal $4.5 \mathrm{eV}$ [17]. $E_{\mathrm{EA}}$ for $\mathrm{Cd}, \mathrm{S}$, and Se are $0 \mathrm{eV}, 2.077 \mathrm{eV}$, and $2.02 \mathrm{eV}$, respectively. Similarly, $E_{\text {ion }}$ for $\mathrm{Cd}, \mathrm{S}$, and Se are $8.99 \mathrm{eV}, 10.36 \mathrm{eV}$, and $9.75 \mathrm{eV}$, respectively. The position of conduction and valence bands of CdS and CdSe are recorded in Table 1. Figure 2(b)

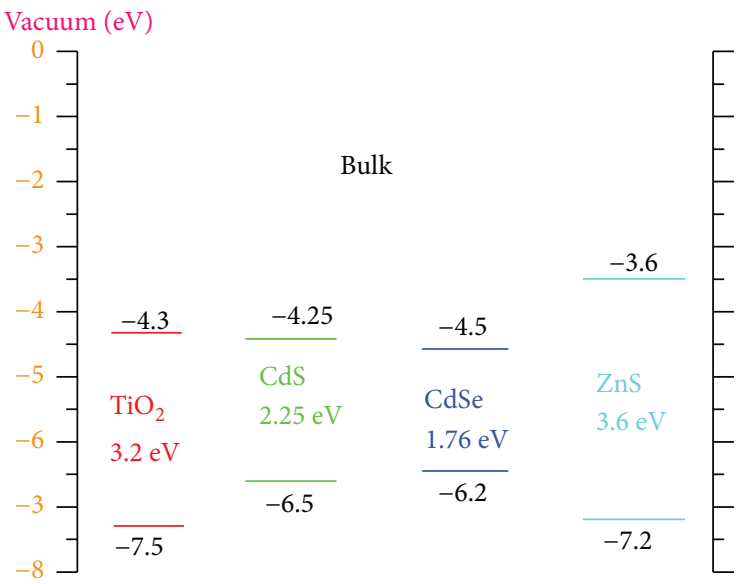

(a)
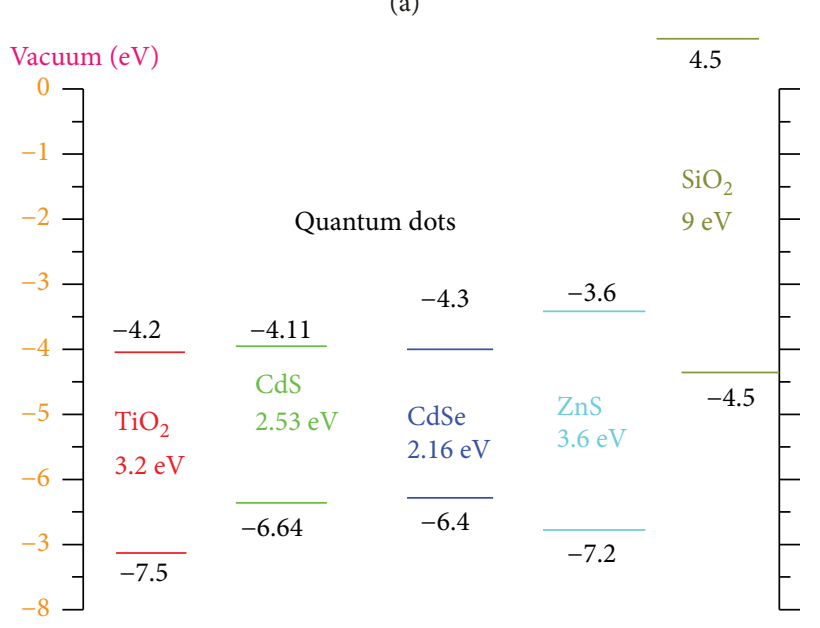

(b)

FIGURE 3: Energy levels alignment of the photoanode: (a) bulk and (b) quantum dots.

can plot $(\alpha \mathrm{h} v)^{2}$ versus the photon energy (hv) using data from the optical absorption spectra. The plotting results are recorded in Table 1. It is immediately remarkable that there is a steadily dropping tendency of energy bandgap from $2.8 \mathrm{eV}$ of pure $\mathrm{TiO}_{2}$ film to $1.83 \mathrm{eV}$ of $\mathrm{TiO}_{2} / \mathrm{CdS} / \mathrm{CdSe} / \mathrm{SiO}_{2}$ film. The obtained results are in good agreement UV-Vis spectra. However, there is a sharp increase in bandgap of CdS and CdSe in bulk and quantum dots. From data in Table 1, it is obvious that the position of conduction and valence bands is shifted toward more negative potential and more positive potential by decreasing the size of particles. Like for instance, the position of conduction and valence bands for CdS shifted toward from $-4.25 \mathrm{eV}$ to $-4.11 \mathrm{eV}$ and from $-6.5 \mathrm{eV}$ to $-6.64 \mathrm{eV}$, respectively. Likewise, the position of conduction and valence bands for CdSe shifted toward between $-4.5 \mathrm{eV}$ and $-4.3 \mathrm{eV}$ and between $-6.2 \mathrm{eV}$ and $-6.4 \mathrm{eV}$, respectively (Figures $3(\mathrm{a})$ and $3(\mathrm{~b})$ ). According to the band-edge alignment of CdS and CdSe in Figure 3, the CdS has a high position of conduction band as that of CdSe. Thus, the transfer of excited electrons from CdS to CdSe and $\mathrm{TiO}_{2}$ facilitates. 


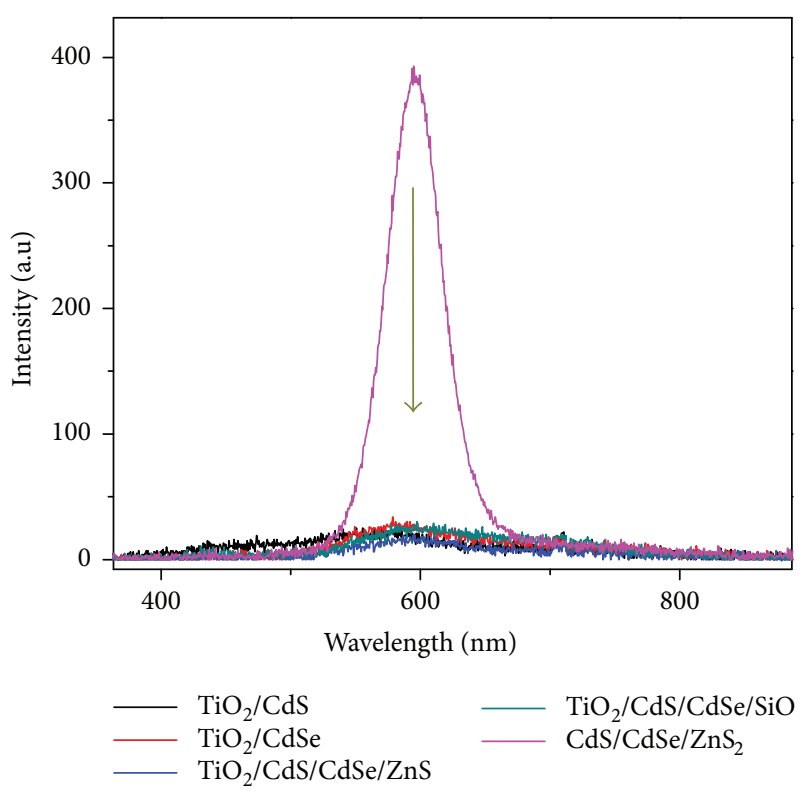

(a)

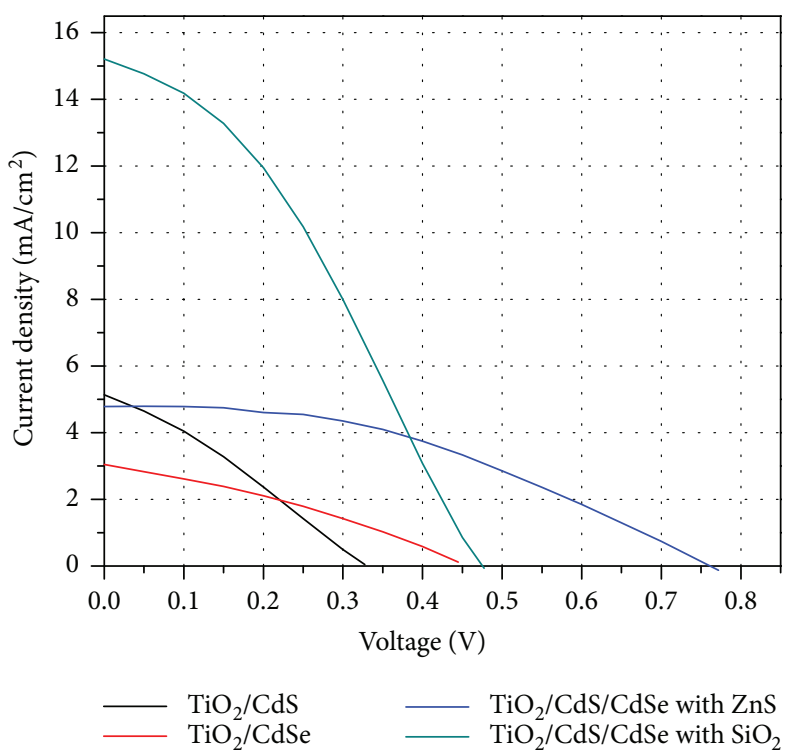

(c)

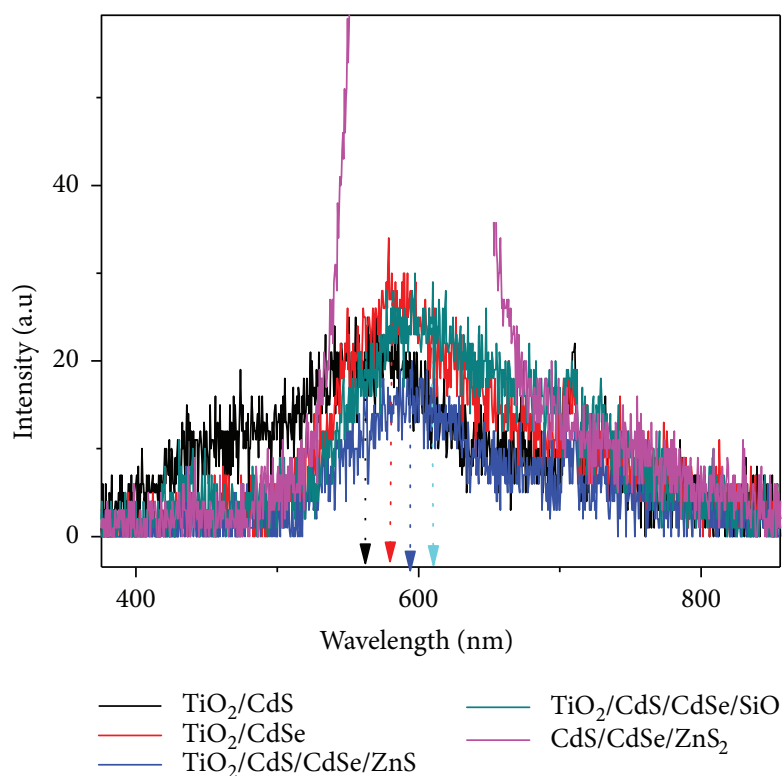

(b)

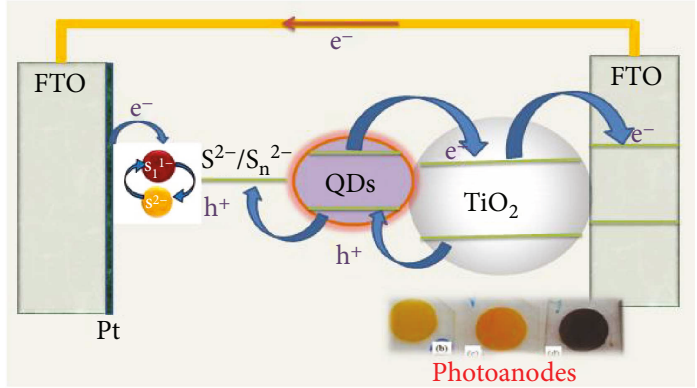

(d)

FIGURE 4: (a, b) Photoluminescence, (c) $J$ - $V$ curves of distrinct photoanodes, and (d) structure and energy levels alignment of the QDSSCs.

To study the relative injected electrons in the $\mathrm{TiO}_{2}$ film from CdS and CdSe QDs, photoluminescence (PL) was carried out (Figures 4(a) and 4(b)). It reveals that there is a significant drop in the $\mathrm{PL}$ of $\mathrm{TiO}_{2} / \mathrm{CdS}, \mathrm{TiO}_{2} / \mathrm{CdSe}, \mathrm{TiO}_{2} / \mathrm{CdS} /$ CdSe with $\mathrm{ZnS}$, and $\mathrm{TiO}_{2} / \mathrm{CdS} / \mathrm{CdSe}$ with $\mathrm{SiO}_{2}$ photoanodes as compared with that of QD films under identical conditions. The bandgap of $\mathrm{TiO}_{2}(3.2 \mathrm{eV})$ limits its absorption range below $400 \mathrm{~nm}$. The CdS QDs have a lower CB than $\mathrm{CB}$ of CdSe QDs ( $3 \mathrm{~nm}$ size). Therefore, the electron injection from the CB of CdSe QDs to the CB of CdS QDs is effective because CdS and CdSe QDs have a higher quasi Fermi levels than that of $\mathrm{TiO}_{2}$. Yella et al. reported that when CdS and CdSe QDs were made a cascade structure, the electrons were injected from CdSe to CdS QDs and then to $\mathrm{TiO}_{2}$ nanoparticles [18]. The redistribution of electrons results in a stepwise band structure. The insertion of a CdS layer between $\mathrm{TiO}_{2}$ and CdSe elevates the CdSe QDs' CB and generates higher driving force for electron transportation. In addition, the quantum confinement effect makes the energy levels of the $\mathrm{CB}$ more negative with decreasing the size of particle [19]. The PL intensity of all photoanodes decreased sharply because the CB of CdSe QDs is as high as that of CdS QDs and $\mathrm{TiO}_{2}$ nanoparticles. Therefore, the electron injection from the $\mathrm{CB}$ of CdSe QDs to the $\mathrm{CB}$ of CdS QDs and $\mathrm{TiO}_{2}$ is effective. Besides, the results reveal that the PL of the anode film loaded with $\mathrm{SiO}_{2}$ is higher than that of the anode film loaded with $\mathrm{ZnS}$. The possible reason is reduced recombination process in nanoparticles, leading to 
TABLE 2: The value parameters of different QDSSCs obtained from $J$ - $V$ curves.

\begin{tabular}{lcccc}
\hline QDSSCs & $\begin{array}{c}J_{\mathrm{SC}} \\
\left(\mathrm{mA} / \mathrm{cm}^{2}\right)\end{array}$ & $\begin{array}{c}V_{\mathrm{OC}} \\
(\mathrm{V})\end{array}$ & $\begin{array}{c}\text { Fill factor } \\
(\mathrm{FF})\end{array}$ & $\begin{array}{c}\text { Efficiency } \\
\eta(\%)\end{array}$ \\
\hline $\mathrm{TiO}_{2} / \mathrm{CdS}$ & 5.5 & 0.35 & 0.30 & 0.7 \\
$\mathrm{TiO}_{2} / \mathrm{CdSe}$ & 5.87 & 0.37 & 0.33 & 0.88 \\
$\begin{array}{l}\mathrm{TiO}_{2} / \mathrm{CdS} / \mathrm{CdSe} \\
\text { with } \mathrm{ZnS}\end{array}$ & 6.01 & 0.76 & 0.43 & 1.92 \\
$\begin{array}{l}\mathrm{TiO}_{2} / \mathrm{CdS} / \mathrm{CdSe} \\
\text { with } \mathrm{SiO}_{2}\end{array}$ & 12.0 & 0.54 & 0.46 & 3.01 \\
\hline
\end{tabular}

increase the PL of nanoparticles. The increase of PL can also boost the emission quantum yield (QY) of QDs, which is helpful for producing more excitons.

3.3. Photovoltaic Performance of the QDSSCs. The characterization by $J-V$ curves provides limited resources to analyze the mechanisms that govern the performance. A thorough analysis requires discriminating several factors such as series resistance, recombination parameters, and carrier energetics. These factors are not commonly available simply by analyzing $J-V$ curve data, notably because $J-V$ curves are elastic with respect the models and can be equally described by many different frameworks. Figure 4(c) illustrates the $J$ - $V$ curves of the QDSSCs with distinct photoanodes with sensitized $\mathrm{TiO}_{2}$ nanoparticles (active area: $0.192 \mathrm{~cm}^{2}$ ) at AM $1.5\left(100 \mathrm{~mW} / \mathrm{cm}^{2}\right)$. All QDSSCs has appeared the $J-V$ characteristic. The performance parameters of QDSSCs are listed in Table 2. The thickness of the QDs was optimized with $\mathrm{CdS}$ (3 layers), CdSe (3 layers), and $\mathrm{SiO}_{2}$ (2 layers) in this work. The $\mathrm{TiO}_{2} / \mathrm{CdS} / \mathrm{CdSe} / \mathrm{SiO}_{2}$ exhibits the highest performance: $\eta=3.01 \%$ (we used $\mathrm{Pt}$ counter electrode), $V_{\text {OC }}=0.54 \mathrm{~V}, J_{\mathrm{SC}}=12 \mathrm{~mA} / \mathrm{cm}^{2}$, and $\mathrm{FF}=0.46$. It is immediately noticeable that $J_{\mathrm{SC}}$ of the QDSSCs improved significant after $\mathrm{SiO}_{2}$ coating and is attributed to the excited electrons characteristics, such as separation, collection, injection, and recombination. The $\mathrm{TiO}_{2} / \mathrm{CdS} / \mathrm{CdSe}$ was coated with $\mathrm{SiO}_{2}$ or $\mathrm{ZnS}$ passivation which increased the significant light harvesting, separation, collection, and injection but reduced recombination.

3.4. EIS of the QDSSCs. The EIS characteristics were found by Mora-Sero et al. [20] to investigate the dynamic processes in the QDSSCs. We can know the information about charge processes through the QDs/ $\mathrm{TiO}_{2} / \mathrm{FTO}$ contacts and diffusion processes of the electrons in electrolyte and $\mathrm{TiO}_{2}$ film. Moreover, the lifetime of electrons can be determined as follows [21].

$$
\tau_{\mathrm{n}}=R_{\mathrm{ct} 2} \cdot \mathrm{CPE}_{2}
$$

Figure 5 illustrates the EIS of the QDSSCs based on the different photoanodes. The Nyquist plots have three semicircles with different frequencies when the concentration of the photoanodes changes. The semicircle at high frequency $(95 \mathrm{~Hz}-1000 \mathrm{kHz})$ is small because of the resistance against the electron diffusion in $\mathrm{FTO} / \mathrm{TiO}_{2}$ and Pt/electrolyte surfaces (denoted by $R_{\mathrm{ct} 1}$ ). The semicircle at the intermediate

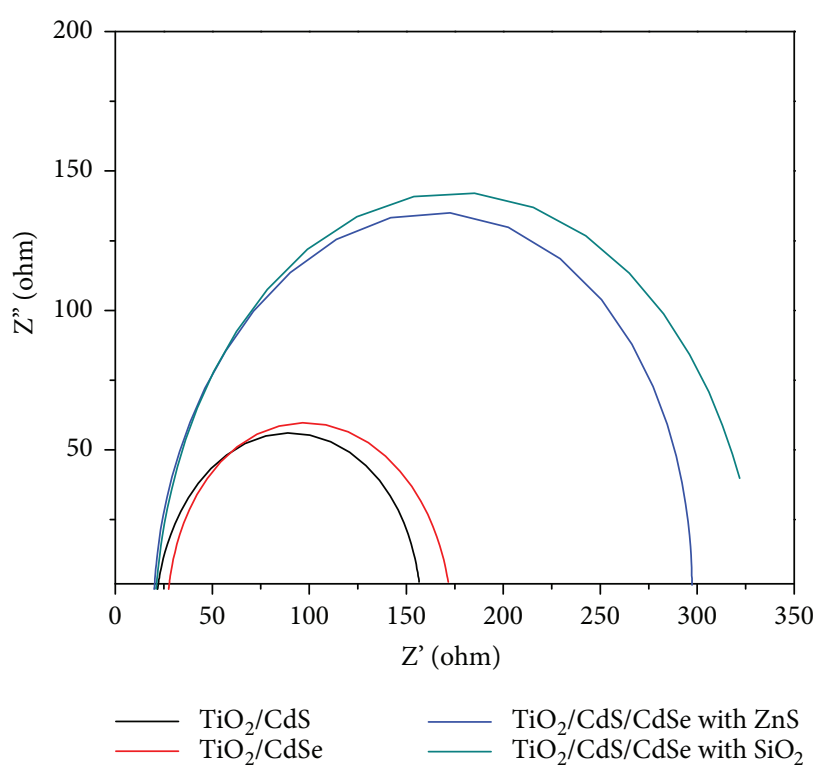

FIgURE 5: Nyquist of the QDSSCs.

frequency $(0.44-95 \mathrm{~Hz})$ is large because of the resistance against the electron diffusion in the $\mathrm{TiO}_{2}$ film and $\mathrm{TiO}_{2} /$ QDs/electrolyte contacts (denoted by $R_{\mathrm{ct} 2}$ ). The semicircle at low frequency $(0.049-0.44 \mathrm{~Hz})$ is because of the diffusion in the $S_{\mathrm{n}}{ }^{2-} / S^{2-}$ electrolyte. $R_{\mathrm{S}}$ is the resistance at the $\mathrm{Ag} /$ FTO front and back contacts of the QDSSCs.

Moreover, we also focused on the dynamic resistance in the QDSSCs, which is determined from the $J-V$ curves. The external resistance is

$$
R_{\mathrm{D}}=\frac{V_{1}-V_{2}}{I_{2}-I_{1}},
$$

the internal resistance is

$$
R_{\mathrm{d}}=\frac{1}{\alpha\left(I_{2}-I_{1}\right)} \ln \left[\frac{I_{\mathrm{ph}}+I_{\mathrm{o}}-I_{1}}{I_{\mathrm{ph}}+I_{\mathrm{o}}-I_{2}}\right],
$$

and the shunt resistance is

$$
R_{\mathrm{SH}}=\frac{V_{\mathrm{OC}}}{I_{\mathrm{ph}}-I_{\mathrm{o}}\left(e^{\alpha V_{\mathrm{OC}}}-1\right)},
$$

where $V$ and $I$ are the voltage and current at the point on the $I$ - $V$ curve; $V_{\mathrm{OC}}, I_{\mathrm{ph}}$, and $I_{\mathrm{o}}$ are the open voltage, short current, and current density saturation, respectively [22]. All resistances are recorded in Table 3.

As can be seen from Figure 5, it is noticeable that the radius of the semicircles increases in the following order: $\mathrm{TiO}_{2} / \mathrm{CdS}, \mathrm{TiO}_{2} / \mathrm{CdSe}, \mathrm{TiO}_{2} / \mathrm{CdS} / \mathrm{CdSe}$ with $\mathrm{ZnS}$, and $\mathrm{TiO}_{2} /$ $\mathrm{CdS} / \mathrm{CdSe}$ with $\mathrm{SiO}_{2}$ passivation. The semicircles for the QDSSCs with $\mathrm{TiO}_{2} / \mathrm{CdS} / \mathrm{CdSe}$ with $\mathrm{ZnS}$ and $\mathrm{TiO}_{2} / \mathrm{CdS} / \mathrm{CdSe}$ with $\mathrm{SiO}_{2}$ retained their shapes, but the radius of the semicircles expanded more because semicircles 1 and 3 were mixed onto semicircle 2 . Therefore, we focus on the change of semicircle 2 at the intermediate frequency. Table 3 illustrates that $R_{\mathrm{ct} 2}$ increased gradually and then peaked at $132 \Omega$ corresponding to $\mathrm{TiO}_{2} / \mathrm{CdS} / \mathrm{CdSe}$ with $\mathrm{SiO}_{2}$ passivation because 
TABle 3: Parameters obtained from the EIS measurements and $J-V$ curves.

\begin{tabular}{lccccccr}
\hline QDSSCs & $R_{\mathrm{D}}(\Omega)$ & $R_{\mathrm{d}}(\Omega)$ & $R_{\mathrm{S}}(\Omega)$ & $R_{\mathrm{SH}}(\Omega)$ & $R_{\mathrm{ct} 1}(\Omega)$ & $R_{\mathrm{ct} 2}(\Omega)$ & $\tau(\mathrm{ms})$ \\
\hline $\mathrm{TiO}_{2} / \mathrm{CdS}$ & 75.3 & 57.2 & 24.56 & 2177 & 127 & 8.07 & 1.592 \\
$\mathrm{TiO}_{2} / \mathrm{CdSe}$ & 60.8 & 33.4 & 27.4 & 5396 & 32.2 & 112 & 2.005 \\
$\mathrm{TiO}_{2} / \mathrm{CdS} / \mathrm{CdSe}$ with $\mathrm{ZnS}$ & 68.6 & 53.1 & 35.5 & 5472 & 103 & 174 & 2.016 \\
$\mathrm{TiO}_{2} / \mathrm{CdS} / \mathrm{CdSe}$ with $\mathrm{SiO}_{2}$ & 92.5 & 74.5 & 53.8 & 13,000 & 179 & 132 & 2.528 \\
\hline
\end{tabular}

of the increase of thickness photoanode. On the contrary, the result from Table 2 gives that the efficiency of QDSSCs-based $\mathrm{TiO}_{2} / \mathrm{CdS} / \mathrm{CdSe}$ with $\mathrm{SiO}_{2}$ photoanode is the highest (3.01\%). This means that $\mathrm{SiO}_{2}$ layer is a passivation to protect CdS and CdSe QDs from electrolyte [23-28] and reduced recombination processes at surface contacts and diffusion in the $\mathrm{TiO}_{2}$ film. In addition to this, I suppose that there was an increase of the electron lifetime of $\mathrm{TiO}_{2} / \mathrm{CdS} / \mathrm{CdSe}$ with $\mathrm{SiO}_{2}$ photoanode-sensitized solar cells and which is near twice that of other photoanode-sensitized solar cells. With this lifetime, the excited electrons are enough time to transfer from CdSe and CdS to $\mathrm{TiO}_{2}$. Thus, the current density of QDSSCs increased sharply. This result is also consistent with that of UV-Vis spectra, PL spectra, and $J-V$ curves. In the same way, the values of resistance dynamic $R_{\mathrm{s}}, R_{\mathrm{D}}$, and $R_{\mathrm{d}}$ enhanced minor while the thickness of photoanodes went up. The results show that the resistance values depended on the thickness of the QD films. External and internal resistances at the same bias voltage under similar illumination conditions are distinct. This is due to the voltage-dependent nature of $R_{\mathrm{d}}$. The dissimilar nature of $R_{\mathrm{d}}$ at different illuminating conditions is also noted. This can be expected as the values of diode factor at different illuminations are not the same. $R_{\mathrm{d}}$ and $R_{\mathrm{D}}$ of each illumination condition can differ approximately $40 \%$. Therefore, a clear distinction should be made when one studies and measures the two types of dynamic resistance.

\section{Conclusions}

In summary, we have successfully enhanced performance QDSSCs based on the distinct electrodes with $\mathrm{ZnS}$ or $\mathrm{SiO}_{2}$ passivation. The highest efficiency of the QDSSCs based on the $\mathrm{TiO}_{2} / \mathrm{CdS} / \mathrm{CdSe}$ with $\mathrm{SiO}_{2}$ passivation electrode is approximately $3.01 \%$, and the short current density is $12 \mathrm{~mA} / \mathrm{cm}^{2}$ compared with that of other electrodes because $\mathrm{ZnS}$ or $\mathrm{SiO}_{2}$ passivation protected $\mathrm{CdS}$ and CdSe QDs from electrolyte and reduced recombination processes at surface contacts and diffusion in the $\mathrm{TiO}_{2}$ film.

\section{Data Availability}

The data used to support the findings of this study are available from the corresponding author upon request.

\section{Conflicts of Interest}

The authors declare no competing interests.

\section{Acknowledgments}

This research is funded by the Vietnam National Foundation for Science and Technology Development (NAFOSTED) under Grant no. 103.03-2016.94. The authors would like to thank Ho Chi Minh City University of Science, Vietnam.

\section{References}

[1] P. V. Kamat, "Quantum dot solar cells. Semiconductor nanocrystals as light harvestors," The Journal of Physical Chemistry C, vol. 112, no. 48, pp. 18737-18753, 2008.

[2] A. Nozik, "Quantum dot solar cells," Physica E: Lowdimensional Systems and Nanostructures, vol. 14, no. 1-2, pp. 115-120, 2002.

[3] M. C. Beard, "Multiple exciton generation in semiconductor quantum dots," The Journal of Physical Chemistry Letters, vol. 2, no. 11, pp. 1282-1288, 2011.

[4] S. S. Mali, S. K. Desai, S. S. Kalagi et al., "PbS quantum dot sensitized anatase $\mathrm{TiO}_{2}$ nanocorals for quantum dot-sensitized solar cell applications," Dalton Transactions, vol. 41, no. 20, pp. 6130-6136, 2012.

[5] J. Jie, Z. Zheng-Ji, Z. Wen-Hui, and W. Si-Xin, "CdS and PbS quantum dots co-sensitized $\mathrm{TiO}_{2}$ nanorod arrays with improved performance for solar cells application," Materials Science in Semiconductor Processing, vol. 16, no. 2, pp. 435440, 2013.

[6] N. P. Benehkohal, V. González-Pedro, P. P. Boix et al., "Colloidal $\mathrm{PbS}$ and $\mathrm{PbSeS}$ quantum dot sensitized solar cells prepared by electrophoretic deposition," The Journal of Physical Chemistry C, vol. 116, no. 31, pp. 16391-16397, 2012.

[7] Q. Zhang, Y. Zhang, S. Huang et al., "Application of carbon counterelectrode on CdS quantum dot-sensitized solar cells (QDSSCs)," Electrochemistry Communications, vol. 12, no. 2, pp. 327-330, 2010.

[8] G.- P. Victoria, X. Xueqing, M.-S. Ivan, and B. Juan, "Modeling high-efficiency quantum dot sensitized solar cells," ACS Nano, vol. 4, no. 10, pp. 5783-5790, 2010.

[9] Y. Zusing and C. Huan-Tsung, "CdHgTe and CdTe quantum dot solar cells displaying an energy conversion efficiency exceeding 2\%," Solar Energy Materials and Solar Cells, vol. 94, no. 12, pp. 2046-2051, 2010.

[10] N. Balis, V. Dracopoulos, K. Bourikas, and P. Lianos, "Quantum dot sensitized solar cells based on an optimized combination of $\mathrm{ZnS}, \mathrm{CdS}$ and $\mathrm{CdSe}$ with $\mathrm{CoS}$ and $\mathrm{CuS}$ counter electrodes," Electrochimica Acta, vol. 91, pp. 246-252, 2013.

[11] D. H. Jara, S. J. Yoon, K. G. Stamplecoskie, and P. V. Kamat, "Size-dependent photovoltaic performance of $\mathrm{CuInS}_{2}$ quantum dot-sensitized solar cells," Chemistry of Materials, vol. 26, no. 24, pp. 7221-7228, 2014. 
[12] J. S. Woo, K. Jae-Hong, K. Hyunsoo, C. Chel-Jong, and A. K. Soon, "ZnS overlayer on in situ chemical bath deposited CdS quantum dot-assembled $\mathrm{TiO}_{2}$ films for quantum dot-sensitized solar cells," Current Applied Physics, vol. 12, no. 6, pp. 1459-1464, 2012.

[13] T. R. Ravindran, A. K. Arora, B. Balamuruga, and B. R. Mehta, "Inhomogeneous broadening in the photoluminescence spectrum of CdS nanoparticles," Nano Structured Materials, vol. 11, no. 5, pp. 603-609, 1999.

[14] R. Vogel, K. Pohl, and H. Weller, "Sensitization of highly porous, polycrystalline $\mathrm{TiO}_{2}$ electrodes by quantum sized CdS," Chemical Physics Letters, vol. 174, no. 3-4, pp. 241246, 1990.

[15] G. I. Koleilat, L. Levina, H. Shukla et al., "Efficient, stable infrared photovoltaics based on solution-cast colloidal quantum dots," ACS Nano, vol. 2, no. 5, pp. 833-840, 2008.

[16] C. Xing, Y. Zhang, W. Yan, and L. Guo, "Band structurecontrolled solid solution of $\mathrm{Cd}_{1-x} \mathrm{Zn}_{x} \mathrm{~S}$ photocatalyst for hydrogen production by water splitting," International Journal of Hydrogen Energy, vol. 31, no. 14, pp. 2018-2024, 2006.

[17] M. Askari, N. Soltani, E. Saion, W. M. Mat Yunus, M. Erfani, and H. M. Dorostkar, "Structural and optical properties of PVP-capped nanocrystalline $\mathrm{Zn}_{x} \mathrm{Cd}_{1-x} \mathrm{~S}$ solid solutions," Superlattices and Microstructures, vol. 81, pp. 193-201, 2015.

[18] A. Yella, H.-W. Lee, H. N. Tsao, C. Yi, A. K. Chandiran, and M. K. Nazeeruddin, "Porphyrin-sensitized solar cells with cobalt (II/III)-based redox electrolyte exceed 12 percent efficiency," Science, vol. 334, no. 6056, pp. 629-634, 2011.

[19] A. Kongkanand, K. Tvrdy, K. Takechi, M. Kuno, and P. V. Kamat, "Quantum dot solar cells. Tuning photoresponse through size and shape control of $\mathrm{CdSe}-\mathrm{TiO}_{2}$ architecture," Journal American Chemistry Society, vol. 130, no. 12, pp. 4007-4015, 2008.

[20] I. Mora-Sero, S. Gimenez, T. Moehl et al., "Factors determining the photovoltaic performance of a CdSe quantum dot sensitized solar cell: the role of the linker molecule and of the counter electrode," Nanotechnology, vol. 19, no. 42, article 424007, 2008.

[21] Q. Wang, S. Ito, M. Gratzel et al., The Journal of Physical Chemistry B, vol. 110, no. 50, pp. 25210-25221, 2006.

[22] J. Thongpron, K. Kirtikara, and C. Jivacate, "A method for the determination of dynamic resistance of photovoltaic modules under illumination," in Proceeding of Technical Digest of the 14th International Photovoltaic Science and Engineering Conference-PVSEC14, Bangkok, Thailand, January 2004https://vi.scribd.com/document/213502631/ThongpronKirtikara-Jivacate-2006-a-Method-for-the-Determination-ofDynamic-Resistance-of-Photovoltaic-Modules-UnderIllumination.

[23] A. Ju-Hyun, R. S. Mane, V. V. Todkar, and S.-H. Han, "Invasion of CdSe nanoparticles for photosensitization of porous $\mathrm{TiO}_{2}$," International Journal of Electrochemistry Science, vol. 2, pp. 517-522, 2007.

[24] T. H. Thanh, V. L. Quang, and H. T. Dat, "Influence of surface treatment and annealing temperature on the recombination processes of the quantum dots solar cells," Journal of Nanomaterials, vol. 2016, Article ID 9806386, 9 pages, 2016.

[25] T. T. Ha, C. H. Chi, N. Vy, N. T. Thoa, T. D. Huynh, and Q. V. Lam, "Improving the performance of QDSSCs based on $\mathrm{Tio}_{2} / \mathrm{CdS}$ (Silar)/CdSe(Colloid)/Zns(Silar) photoanodes," Environmental Progress \& Sustainable Energy, vol. 34, no. 6, pp. 1774-1779, 2015.
[26] T. H. Thanh, V. L. Quang, and D. H. Thanh, "Determination of the dynamic resistance of the quantum dots solar cells by one I-V curve and electrochemical impedance spectra," Solar Energy Materials and Solar Cells, vol. 143, pp. 269-274, 2015.

[27] T. H. Thanh, L. Q. Vinh, and H. T. Dat, "The dynamic resistance of $\mathrm{CdS} / \mathrm{CdSe} / \mathrm{ZnS}$ co-sensitized $\mathrm{TiO}_{2}$ solar cells," Brazilian Journal of Physics, vol. 44, no. 6, pp. 746-752, 2014.

[28] J. Chang, T. Oshima, S. Hachiya et al., "Uncovering the charge transfer and recombination mechanism in ZnS-coated PbS quantum dot sensitized solar cells," Solar Energy, vol. 122, pp. 307-313, 2015. 

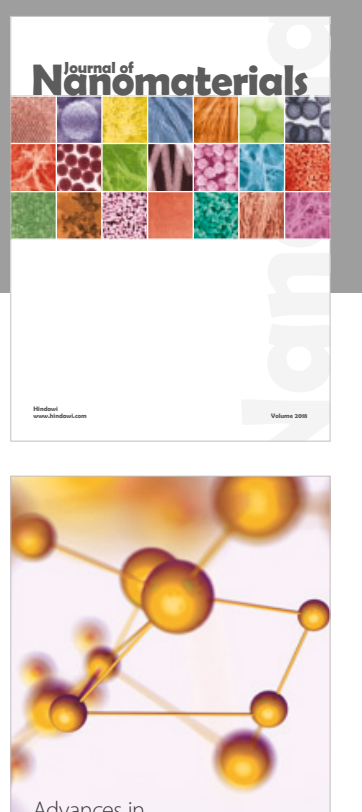

Physical Chemistry
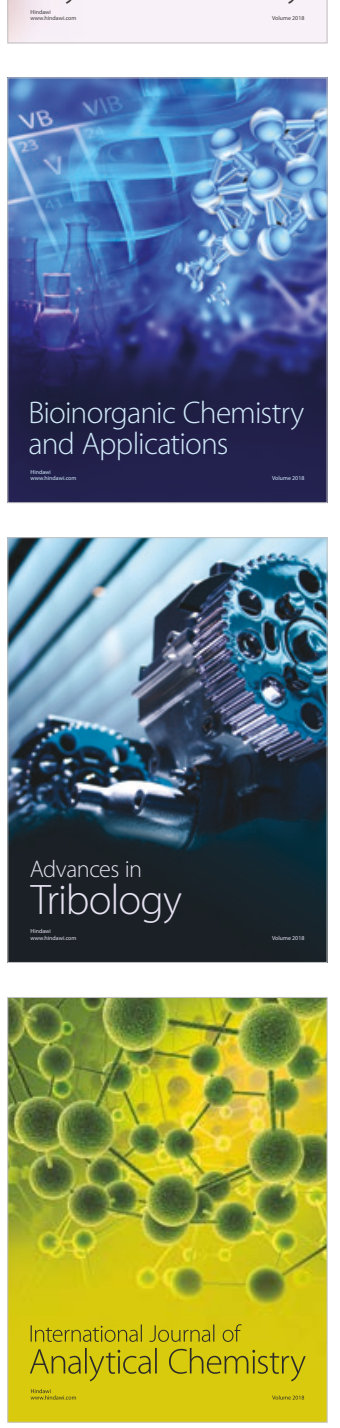

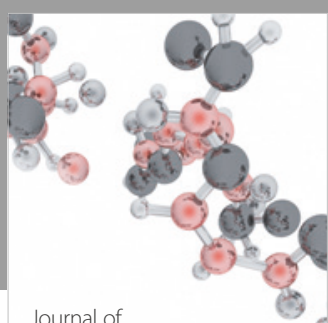

Analytical Methods

in Chemistry

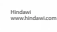

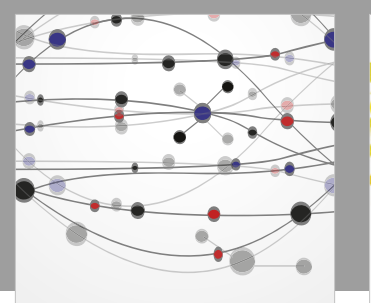

The Scientific World Journal

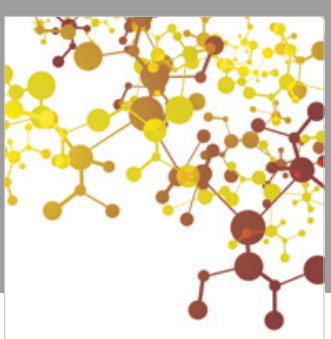

Journal of

Applied Chemistry
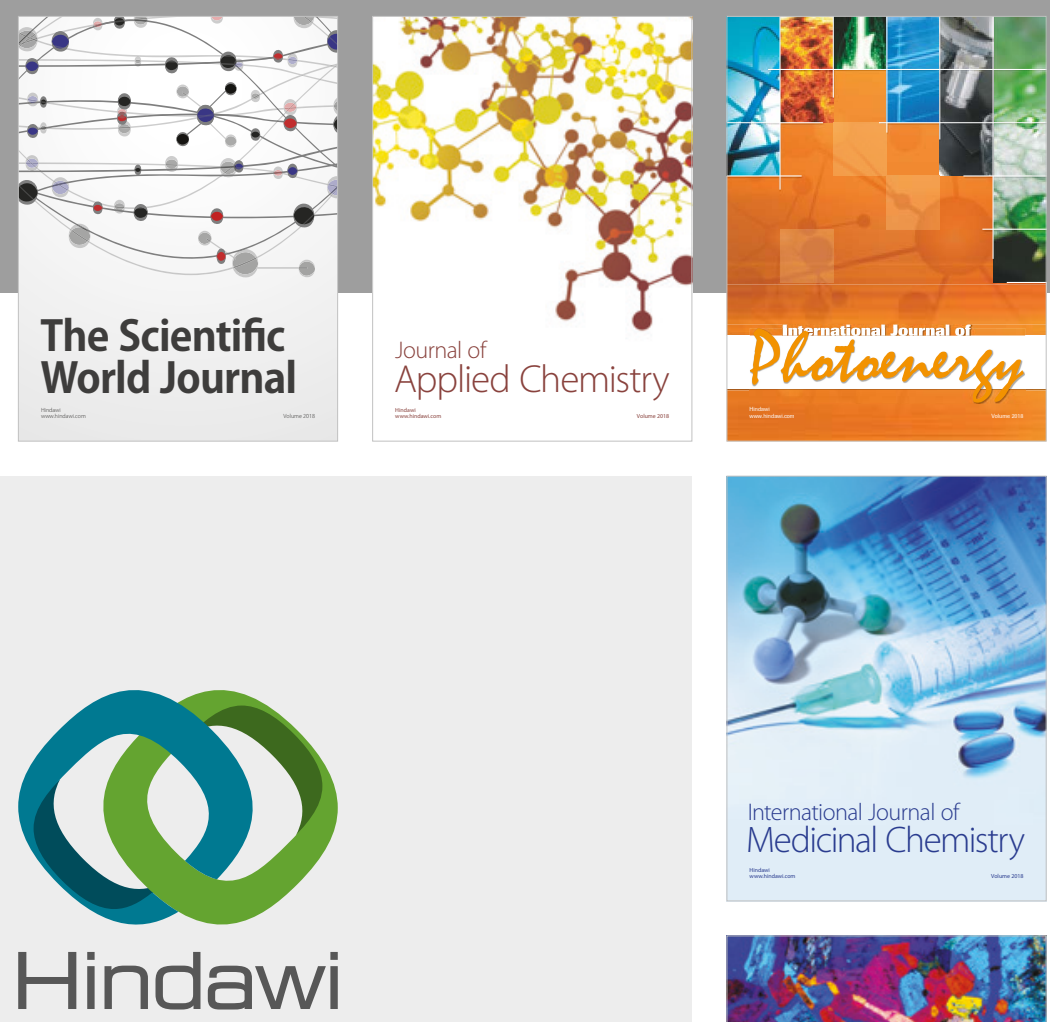

Submit your manuscripts at

www.hindawi.com
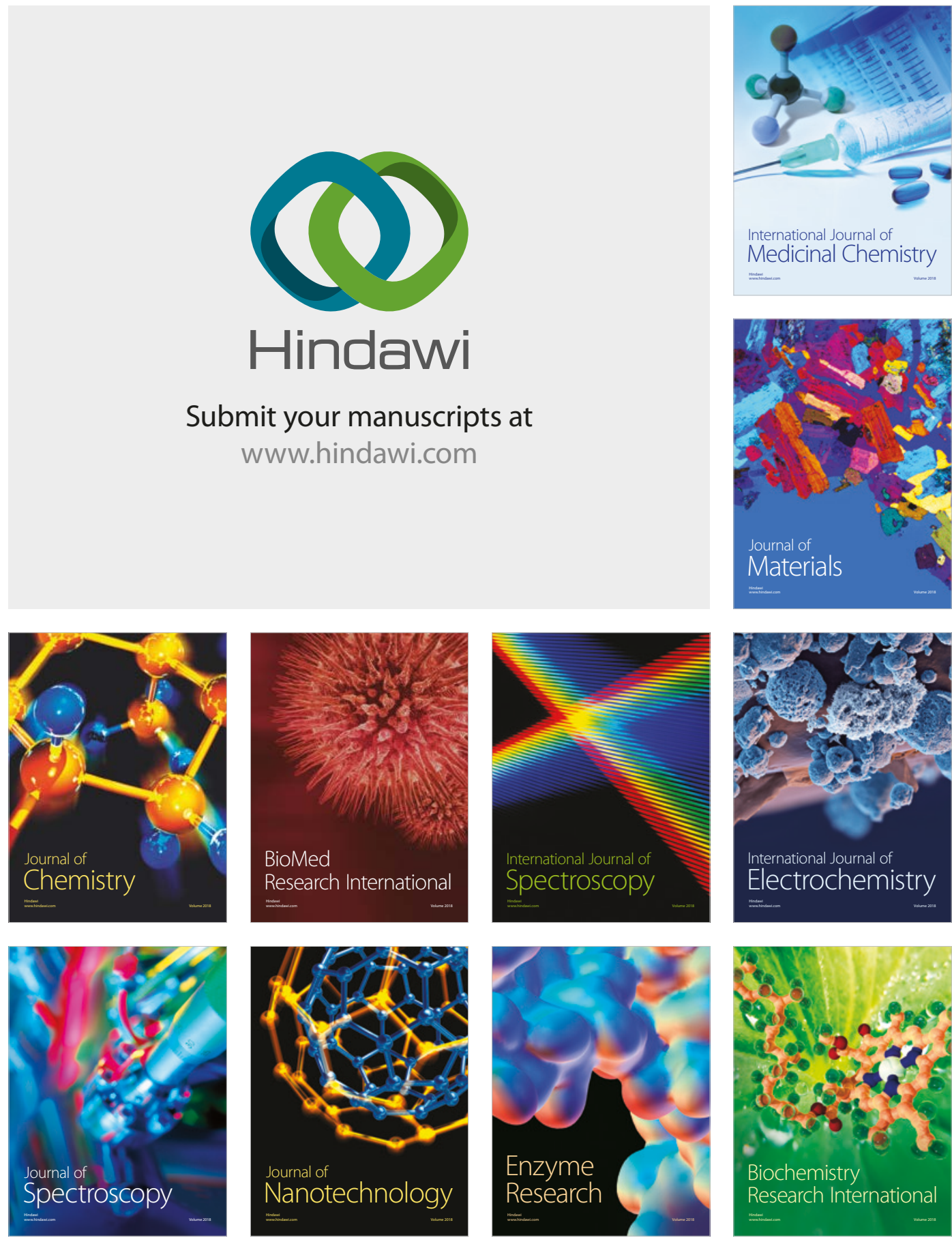
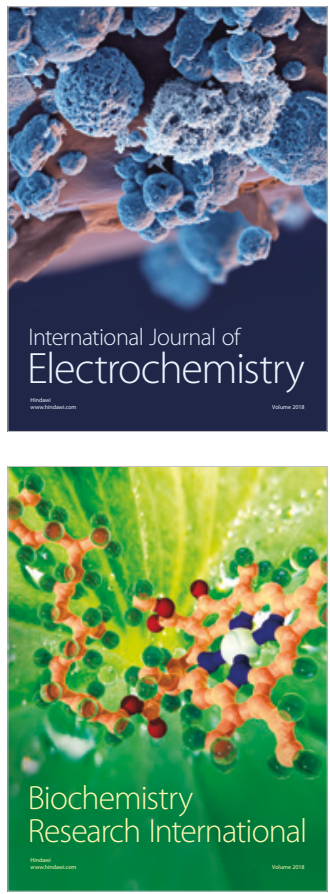